\title{
ANALYSIS OF VOLATILITY AND CONTAGION EFFECT OF COUNTRIES FROM LATIN AMERICA
}

Guilherme Freitas Cardoso ${ }^{1}$ Guilherme Santos Souza ${ }^{2}$ Luciano Ferreira Carvalho ${ }^{3}$ (D) Karem Cristina de Sousa Ribeiro $^{4}$ ${ }^{1}$ Mestre, Universidade Federal de Uberlândia - UFU. Uberlândia, Minas Gerais - Brasil.guilhermefc05@ gmail.com ${ }^{2}$ Mestre, Universidade Federal de Uberlândia - UFU. Uberlândia, Minas Gerais - Brasil. guilhermessantos042@ gmail.com ${ }^{3}$ Doutor, Universidade Federal de Uberlândia - UFU. Uberlândia, Minas Gerais-Brasil.lucianofc1906@gmail.com ${ }^{4}$ Doutora, Universidade Federal de Uberlândia - UFU. Uberlândia, Minas Gerais - Brasil. kribeiro@ufu.br

Abstract

Objective: The volatility is a concern for investigators and scholars, both trying to understand and predict with a logical way the dispersion of returns for a given security or market index, but these movements have shown irregular, complex, and increasingly less influence of individual factors. Thus, the research investigates the volatility of the returns and checks out the comovements and countries' contagion effects from Latin America.

Methodology: The sample comprises daily data from January 2002 to December 2016 to measure the volatility of countries' stock exchanges from Latin America. An Autoregressive model with Conditional Heteroscedasticity - ARCH/GARCH models was used to measure the volatility. To check the stock exchanges' contagion effects we used volatility models, vector autoregression models (VAR).

Originality: The impact and behavior of volatility over the markets have been a significant concern for researchers and practitioners regarding the returns' spread. To better understating the contagion in emerging markets, specifically, the Latin American markets may present as a diversification opportunity to investors, and a set of rules be implemented to improve these markets' regulations.

Main results: The results indicate evidence of a contagion effect, which it was observed in all countries, with two facts being relevant, the first is the influence of the Brazilian stock exchange in all other countries in the sample and, lastly, the low representativenes of endogenous factors to explain the volatility behavior of the stock exchange from Mexico. Also, it demonstrates that during the period of higher volatility, subprime crisis, the correlations displayed higher volatility between than during the other periods, which demonstrated that diversification benefits decrease during more volatile periods. It was found that the Brazilian stock exchange has a significant influence on Argentina. The same influence is not observed when analyzing the strength of the Argentine stock exchange over the Brazilian stock market.

Theoretical Contributions: Better understanding of volatility and its ripples effects among the Latin American markets are relevant to investors and policymaker concerning the flow of investments and enforcement of regulations. Also, we provide evidence of during the period of higher volatility, the diversification benefits decrease. Moreover, the contagion effect was observed in all countries, with two facts being relevant. The first one is the influence of the Brazilian stock exchange in all othe countries in the sample and the low representativeness of endogenous factors to explain the volatility behavior of Mexico's stock exchange.

Keywords: Volatility. Comovements. Contagion effect.

\section{ANÁLISE DA VOLATILIDADE E EFEITO CONTÁGIO DOS PAÍSES DA AMÉRICA LATINA}

\section{Resumo}

Objetivo do Trabalho: A volatilidade consiste em uma preocupação para investidore e acadêmicos, ambos tentando entender e prever, de forma lógica, a dispersão de retornos para um determinado índice de segurança ou mercado, mas esses movimentos têm mostrado uma influência irregular, complexa e cada vez menor de fatores individuais. Assim, o objetivo da pesquisa é investigar a volatilidade dos retornos verificar os co-movimentos e o efeito contágio dos países da América Latina.

Metodologia: A amostra compreende dados diários de janeiro de 2002 a dezembro de 2016 para medir a volatilidade das bolsas de valores de países da América Latina, utilizando-se um modelo de regressão automática com modelos de heterocedasticidade condicional, ARCH/GARCH. Para verificar os efeitos do contágio nas bolsas de valores, utilizou-se modelos de volatilidade e modelos de regressão automática vetorial (VAR). Originalidade: $\mathrm{O}$ impacto e o comportamento da volatilidade nos mercados tem sido uma grande preocupação para pesquisadores e profissionais em relação à disseminação dos retornos. Um melhor entendimento do contágio nos mercados emergentes, especificamente os mercados latino-americanos, pode se apresentar como uma oportunidade de diversificação para os investidores e um conjunto de regras a serem implementadas, para melhorar as regulamentações nesses mercados.

Principais Resultados: Os resultados indicam evidências de um efeito contágio em todos os países, com dois fatos relevantes, o primeiro é a influência da bolsa brasileira em todos os outros países da amostra e, o outro, é a baixa representatividade dos fatores endógenos para explicar o comportamento de volatilidade da bolsa de valores do México. Os resultados também demonstraram que, durante o período de maior volatilidade, a crise subprime, as correlações apresentaram maior volatilidade entre os demais períodos, identificando que os benefícios da diversificação diminuem durante períodos mais voláteis. A partir disso, foi possível constatar que a bolsa brasileira tem grande influência na Argentina, mas a mesma influência não é observada quando se analisa a força da bolsa de valores argentina, sobre o mercado acionário brasileiro. Contribuições Teóricas: Melhor entendimento da volatilidade e dos efeitos ondulantes entre os mercados latino-americanos, assim como sua relevância para investidores e formuladores de políticas, no que diz respeito ao fluxo de investimentos e à aplicação de regulamentos. Além disso, fornecemos evidências de que, durante o período de maio volatilidade, os benefícios de diversificação diminuem, sendo observado o efeito de contágio em todos os países, com dois fatos relevantes, o primeiro é a influência da bolsa de valores brasileira em todos os outros países da amostra e, o segundo, a baixa representatividade de fatores endógenos para explicar o comportamento da volatilidade da bolsa de valores do México.

Palavras-chave: Volatilidade. Co-movimentos. Efeito contágio.

\section{ANÁLISIS DE LA VOLATILIDAD Y EL EFECTO DEL CONTAGIO DE LOS PAÍSES DE AMÉRICA LATINA}

\section{Resumen}

Objetivo del trabajo: La volatilidad comprende una preocupación para los inversionistas y académicos, ambos intentan comprender y predecir de manera lógica la dispersión de los rendimientos para un índice de mercado o seguridad determinado, pero estos movimientos han mostrado una influencia irregular, compleja y cada vez menos influenciada de factores individuales. Por lo tanto, el objetivo de la investigación es investigar la volatilidad de los retornos y verificar los movimientos conjuntos y los efectos de contagio en los países de América Latina.

Metodología: La muestra comprende datos diarios desde enero de 2002 hasta diciembre de 2016 para medir la volatilidad de las bolsas de valores de los países de América Latina. Para medir la volatilidad, se usó un modelo Regresivo automático con Heteroscedasticidad condicional, ARCH/GARCH. Para verificar los efectos de contagio en las bolsas de valores, utilizamos modelos de volatilidad, modelos de regresión automática de vectores (VAR).

Originalidad: El impacto y el comportamiento de la volatilidad en los mercados ha sido una preocupación importante para los investigadores y profesionales con respecto a la difusión de los retornos y la mejor subestimación del contagio en los mercados emergentes, específicamente, los mercados latinoamericanos pueden presentar una oportunidad de diversificación. a los inversores y un conjunto de reglas implementadas para mejorar las regulaciones en estos mercados.

Principales resultados: Los resultados indican que se observó evidencia de un efecto de contagio en todos los países, con dos hechos relevantes, el primero es la influencia de la bolsa de valores brasileña en todos los demás países de la muestra y, por último, la baja representatividad de los factores endógenos Para explicar el comportamiento de la volatilidad de la bolsa de valores de México. Los resultados indican que durante el período de mayor volatilidad, la crisis subprime, las correlaciones mostraron una mayor volatilidad que durante los otros períodos, lo que demostró que los beneficios de diversificación disminuyen durante los períodos más volátiles, y se encontró que la bolsa de valores brasileña tiene una gran influencia en Argentina, y no se observa la misma influencia al analizar la fortaleza de la bolsa de valores argentina sobre el mercado de valores brasileño.

Contribuciones teóricas: Una mejor comprensión de la volatilidad y sus efectos en los mercados latinoamericanos sobre cómo son relevantes para los inversores y los encargados de formular políticas con respecto al flujo de inversiones y la aplicación de las regulaciones. Además, proporcionamos evidencia de que durante el período de mayor volatilidad disminuyen los beneficios de diversificación. Además, se observó un efecto de contagio en todos los países, siendo relevantes dos hechos, el primero es la influencia de la bolsa de valores brasileña en todos los demás países de la muestra y, por último, la baja representatividad de los factores endógenos para explicar el comportamiento de volatilidad de La bolsa de valores de México.

Palabras-chaves: Volatilidad. Co-movimientos. Efecto contagio.

Cite as / Como citar

American Psychological Association (APA)

Cardoso, G. F., Souza, G. S., Carvalho, L. F., \& Ribeiro, K. C. de S. (2020, Oct./Dec.). Analysis of volatility and contagion effect of countries from Latin America. Iberoamerican

Journal of Strategic Management (IJSM), 19(4), 41-57. https://doi.org/10.5585/riae.v19i4.14457. 


\section{Introduction}

Studies in Finance went through several changes over the understanding of the relationship between risk and return since the seminal work of Markowitz - Portfolio Selection (1952) - based on the principle that investors should seek assets with a low and negative correlation over their returns. According to recent researches, the volatility of stock exchanges, from market comovements aftershocks, triggers the process of movement in exchange rates, stocks, sovereign bonds, and capital flows (e.g., Forbes \& Rigobon, 2002; Pericoli \& Sbracia, 2003; Vartanian, 2012; Panda \& Nanda, 2018; Sarwar, 2019). Understand the comovements concerns practical issues that policymakers and investors have to deal with, especially in emerging markets due to its high volatility, dependence, and connectedness with the developed markets.

The volatility comprehends a concern for practitioners and scholars. Both try to understand and predict the dispersion of returns for a given security or market index in a logical way. However, these movements have shown irregular, complex, and, increasingly less influence on individual factors. As reported for Broto, Díaz-Cassou \& Erce-Dominguez (2011), the country-specific factors have reduced due to globalization forces. The volatility of the markets driven by global factors is beyond the control of emerging countries.

Diversification is a risk management technique that mixes a wide variety of investments within a portfolio, wherein aims to smooth out unsystematic risk in a portfolio. Hence, the positive performance of some investments neutralizes the negative performance of others. However, the movements between the assets direct affect their volatilities because correlated external forces drive them. According to Harvey (1995), emerging countries' market performance can be impressive and highly volatile. The correlations of the assets return from emerging countries are lower than those from developed countries. As a result, it may be possible to lower portfolio risk by participating in emerging markets. Therefore, some scholars argue for the need to estimate the degree of correlation of emerging markets' returns, identifying developed countries separately.

The spillovers into countries' economics caused for crises worldwide have been subject to research about the contagion effect since the Tequila crisis of 1994-95, the Asian flu of 1997, and the Russian virus of 1998 (Kaminsky \& Reinhart, 2000). The emerging markets in Latin America awakened from the Tequila crisis. Given the heterogeneity in macroeconomic fundamentals across countries, these comovements could be interpreted as indications of herding behavior on the part of investors (Forbes \& Rigobon, 2002).

Financial market volatility is central to the theory and practice of asset pricing, asset allocation, and risk management (Andersen, Bollerslev, Diebold \& Ebens, 2000). A common belief is that there are asset classes with low-negative correlations in international markets, particularly in emerging or frontier markets. So most studies analyze such correlations among stock market return (Baumöhl \& Lyócsa, 
2014). In this context, this paper will investigate the volatility of the returns to check out the comovements and the contagion effects of countries from Latin America.

The sample comprises daily data from January 2002 to December 2016 to measure the volatility of countries' stock exchanges from Latin America. To measure the volatility, it used an Autoregressive model with Conditional Heteroscedasticity, ARCH/GARCH models. We use volatility models, vector autoregression models (VAR) to check the stock exchanges' contagion effects. The understanding of volatility and its ripples effects among the Latin American markets are relevant to investors and policymakers concerning the flow of investments and the enforcement of regulations. The results indicate that during the period of higher volatility, the diversification benefits decrease. All countries observed the contagion effect with two relevant facts; the first is the influence of the Brazilian stock exchange in all the other countries in the sample; the second the low representativeness of endogenous factors to explain the volatility behavior of the stock exchange from Mexico.

The next section presents the theoretical framework; after that, are the methods, data, and sample; the results and discussions are on-topic 4. The last part summarizes the concluding remarks, limitations, and suggestions for future ones.

\section{Literature review}

\section{Theoretical background}

According to Markowitz (1952), diversification should guide selecting a portfolio process, even though sensible. However, behavior rules that do not imply the superiority of diversification must be rejected as a hypothesis and maxim. Bollerslev, Chou \& Kroner (1992), portray volatility as the primary variable that transits most financial instruments and acts as the main driver in several economics and finance areas. For Gaio, Pessanha, de Oliveira \& de Ázara (2007), volatility can be understood as one of the most significant variables for financial agents. Its importance is to observe the direction and speed of securities of movements.

Examining the relationship between stock returns and stock market volatility French, Schwert $\&$ Stambaugh (1987) found indirect evidence of a positive relationship between expected risk premiums and volatility. This finding is associated with the stock market returns are negatively related to the unexpected change in stock returns volatility. Schwert (1988) analyzed the relationship of stock volatility with real and nominal macroeconomic volatility, financial leverage, stock trading, default risk, and company performance. He found that leverage has an insignificant effect on stock volatility and that fluctuations in aggregate stock volatility are difficult to explain using stock valuation models.

Glosten, Jagannathan \& Runkle (1993) presented a counterpoint to the belief that monthly volatility would be persistent, using modified model GARCH-M. In this case, positive unplanned returns seem to result in a downward revision of conditional volatility, while unanticipated negative returns result in an upward revision of conditional volatility. 
Studying the dynamic behavior of stocks and volatility in emerging financial markets, De Santis (1997) found strong evidence of variable volatility time, highly persistent changes, and predictable in almost all countries. Besides, in its statistical analysis, the fat-tailed distribution fits better than the normal distribution, and the stock market risk assumed does not reward the investors.

In their study, Ahmed \& Sarfraz (2013) measured volatility and examined the relative volatility of emerging and developed markets. These authors linked volatility with the global stock market index. In emerging markets, they found indices with a higher ratio of non-normality and peaks. For the developed markets, they found a more significant volatility relation than in the emerging stock markets.

Emerging countries have structures for the distribution of securities returns, usually most unstable. Local and global influence frequently vary from country to country, as these countries' stock markets become integrated. The information at global levels is relatively more critical and correlated in the volatility behavior of the countries' stock exchanges (Harvey, 1995).

The stock market linkages' study has increased in recent decades, mainly the emergent markets' impacts. Baumöhl and Lyócsa (2014) found in their study that asymmetry in volatility is not a common phenomenon in emerging and frontier markets, and the relationship between volatility and correlations is positive and significant in most countries. Thus, diversification benefits decrease during periods of higher volatility.

Forbes \& Rigobon (2002) analyzed the three major crises (Asian crisis, 1997, Mexican devaluation, 1994, fall in the North American market, 1987) and showed that the coefficients explain the market's correlation, conditioned by market volatility. In this sense, the authors did not notice any correlation coefficients during these crises, refuting the contagious effect. There is only interdependence among the markets. Opposing Corsetti, Pericoli \& Sbracia (2005) developed a contagion test study based on bivariate correlation analysis, generalizing existing tests and applying them to the international effects of the Hong Kong crisis 1997. The authors found evidence of contagion effect in 5 countries of their sample of 17.

\section{Markets correlations and contagion effect}

Correlations between international equity market returns tend to increase in highly volatile bear markets, which has led some to doubt international diversification benefits. Regime changes and currency hedging are still valuable in international diversification. The costs of ignoring the regimes are small for all-equity portfolios but increase when a conditionally risk-free asset can be held (Ang \& Bekaert, 2002). Longin \& Solnik (2001) found that correlation is not related only to the market volatility but also to the market trend. They also found that correlations increase in bear markets, but not in bull markets.

Corsetti et al. (2005) argue that many studies associate the idea of correlation in a growing or high level of volatility with the presence of contagion. Such an idea may lead to erroneous evaluations 
under certain circumstances. The existence of interdependence is also consistent with upward correlation or volatility. Therefore, Corsetti et al. (2005) propose that the contagion notion is associated with an increased correlation beyond that expected by some interdependence pattern. Contagion would be associated with the excessive increase of correlations between the country generating the crisis and the others.

Following the model of Corsetti et al. (2005), Perobelli, Vidal \& Securato (2013) found that the Asian crisis of 1997 had the most contagion effect on the other markets. The other ones were the terrorist attacks of September 11, the Brazilian crisis of 1999, the internet bubble of 2000, and the subprime crisis; other events had only restricted shocks on the origin countries.

Longstaff (2010) investigate the effects of collateralized debt obligations (CDOs) on the other markets during the subprime crisis. The results indicate that financial contagion was propagated primarily through liquidity and risk-premium channels, rather than through a correlated-information channel, which provided evidence from financial contagion spillover markets as the development of the subprime crisis.

Patton (2004) compared a portfolio's performance based on a normal distribution model with a portfolio based on a more flexible distribution model. The findings are that for investors with no shortsales constraints, the gains are limited. The knowledge of higher moments and asymmetric dependence leads to economic significant and statistically significant gains in some cases.

Aloui, Ben Aïssa \& Nguyen (2011), in their study about the correlations of the BRIC and the U.S. markets, found strong evidence of time-varying dependence between these markets, and the dependency is stronger for commodity-price than for finished-product export-oriented. They also showed that these markets' dependence is still the same during both bullish and bearish markets.

The definition of contagion is still under discussion in the literature, and according to Pericoli \& Scrabia (2003), at least five definitions have been adopted. The consensus is the qualitative and quantitative impact, causing structural breaks in the data, being estimated the regime changes described as Markov processes, or testing significant changes in the correlation of asset returns. They also lack a possible and testable theoretical model to evaluate the contagion channels' empirical relevance.

Implications of the literature of the contagion effect to Latin American countries are to understand better how to reduce a country's vulnerability to external shocks. According to Forbes \& Rigobon (2002), when the crisis is originated elsewhere in the world, the short-run isolation strategies can be highly effective in reducing the effects of a crisis. Nevertheless, when the crisis is worldwide, the short-run strategies are not sufficient. They will only delay a country's adjustment to a shock, not prevent it. Chen, Firth \& Rui (2000) suggest that the potential for diversifying risk by investing in different Latin American markets is limited, and Edwards \& Susmel (2001) and Fujii (2005), which evidenced robust evidence of comovements of volatility among Latin America countries.

The monetary policy dilemma deals with a global financial cycle that synchronizes international capital movements and asset price changes across countries. Two factors - global investors' risk 
preference and global uncertainty - are regarded as important global common factors that drive that cycle. These comovements' driving forces include increasing international trade and Finance, business climate, and institutional opaqueness. The time-varying factors also include indicators representing monetary policy and capital controls, supporting a policy implication of a global financial cycle hypothesis (Inaba, 2018). The increased connectivity of their markets leads to global factors affecting them, related to the world's largest economies' interest rate and inflation. The local factors are money supply and rates. The Latin American markets' comovement is more synchronous than usual in crisis and capital liberalization (Panda and Nanda, 2018).

\section{Sample and methodology}

The data used for empirical analysis refer to the time series returns of the four stock exchanges from Latin America, which are BMF\&Bovespa (BVSP), Mexbol (MXX), Bolsa de Comercio de Buenos Aires (MERVAL), and Bolsa de Comercio Santiago (IPSA). The frequency of data is daily, and the period runs from January 2002 to December 2016. This period was selected to portrait economic cycles of stability, credit expansion, external and internal crises. The data source is Yahoo Finance.

Table 1 - Summary of sample information

\begin{tabular}{cccc}
\hline Country & Ticker Stock Exchange & Turnover & Initial Period Analysis \\
\hline Brazil & BVSP & $60,227.29$ & $01 / 02 / 2002$ \\
Mexico & MXX & $45,642.89$ & $01 / 02 / 2002$ \\
Argentina & MERVAL & $16,917.86$ & $01 / 02 / 2002$ \\
Chile & IPSA & $4,151.39$ & $01 / 02 / 2002$ \\
\hline
\end{tabular}

Note: $\mathrm{BVSP}=\mathrm{BMF} \&$ Bovespa $; \mathrm{MXX}=$ Mexbol; MERVAL $=$ Bolsa de Comercio de Buenos Aires; IPSA = Bolsa de Comercio Santiago.

Source: Prepared by the authors.

To measure volatility, we used autoregressive models with conditional heteroscedasticity (ARCH) and GARCH (Generalized ARCH). According to Morettin (2004), the basic idea is that the error term (Xt) of an auto model regression for a variable $\mathrm{Yt}$ is not serially correlated, but the volatility (conditional variance) depends on past returns employing a quadratic function. An ARCH/GARCH model can be represented according to equations one, two, three, and four presented below: 


$$
\begin{aligned}
& Y_{t}=\beta_{0}+\beta_{1} \beta Y_{t-1}+\ldots+\beta_{1} \beta Y_{t-p}+X_{t} \\
& X_{t}=\sqrt{h_{t} \varepsilon_{t}} \\
& h_{t}=\alpha_{0}+\alpha_{1} X_{t-1}^{2}+\ldots+\alpha_{r} X_{t-r}^{2}
\end{aligned}
$$

$h_{t}$ is the conditional variance; $\varepsilon_{t}$ is an independent and identically distributed sequence of variables (i.i.d.) with zero mean and variance equal to one $\mathrm{N} \sim(0,1) ; \alpha_{0}$ is the intercept; $\alpha_{1}$ is the coefficient of the auto-regressive component.

Considering an autoregressive model with that estimated in equation 1 , the conditional variance in a GARCH $(r, s)$ model can be given by:

$$
h_{t}=\alpha_{0}+\sum_{i=1}^{r} \alpha_{1} X_{t-1}^{2}+\sum_{i=1}^{r} \beta_{j} h_{t-j}
$$

In that, $\beta \mathrm{j}$ represents the parameter of the autoregressive component of volatility, and $\varepsilon t$ is a sequence of independent and identically distributed variables (i.i.d.) with zero mean and variance one $\mathrm{N}$ $\sim(0,1)$.

Volatility models estimation, autoregression vector (VAR) models, and vector with error corrections (VEC) were tested to check the co-movements between the countries, the contagion effect. The VAR model can be written as follows:

$$
Z_{t}=A_{1} Z_{t-1}+\ldots+A_{k} Z_{t-k}+\varnothing D_{t}+\mu_{t}
$$

Where $\mu_{t} \sim \operatorname{IN}(0, \Sigma), Z_{t}$ is a vector $(\mathrm{n} \times 1)$ and each element $A_{1}$ is an array of order parameters (n $\mathrm{x} \mathrm{n}$ ) and $D_{t}$ represents deterministic terms, such as constant, linear trend and seasonality. For the study were used for the system of simultaneous regressions, explained by the equations:

$$
\begin{aligned}
& \beta G \operatorname{archBVSP}=\beta \operatorname{Garch} M X X+\beta \operatorname{Garch} M E R V A L+\beta G \operatorname{archIPSA} \\
& \beta G \operatorname{arch} M X X=\beta \operatorname{Garch} B V S P+\beta G \operatorname{arch} M E R V A L+\beta \operatorname{GarchIPSA} \\
& \beta G \operatorname{arch} M E R V A L=\beta \operatorname{Garch} B V S P+\operatorname{Garch} M X X+\beta \operatorname{GarchIPSA} \\
& \beta G \operatorname{archIPSA}=\beta G \operatorname{arch} B V S P+\operatorname{Garch} M X X+\beta G \operatorname{arch} M E R V A L
\end{aligned}
$$


It was necessary to analyze the sample to identify whether the variables would be stationary or not, to use the autoregressive vector (VAR) model. From the principle that the GARCH series are all initially stationary, the final model uses the autoregressive vector - VAR, and it is not necessary to use the vector with error corrections - VEC.

Phillips-Perron (PP) developed the unit root that confirms whether the series has a unit root or if the stationary process generated the variable and Augmented Dickey-Fuller (ADF), the extension of the Dickey-Fuller test that aims to delete any serial correlation. After the unit root tests, it was necessary to verify if the series would be cointegrated through the Johansen cointegration test. In this case, if no cointegration is observed, the vectors autoregressive (VAR) is used. If the cointegration is observed, the vector with error corrections (VEC) is used. For the development of the VAR, it was necessary to identify the number of lags, according to the Akaike Information Criterion (AIC), and defining the ordering of the variables using the Granger and Block test.

\section{Results and discussions}

The descriptive statistics of the volatility stock exchanges analyzed are presented in Figure 1. As noticed, all countries had high peaks of volatility during the subprime crisis, as evidenced by Perobelli et al. (2013). This crisis occurred from September 26, 2007, to March 17, 2009, which affected these markets afterward.

Figure 1 - The volatility of the stock exchanges
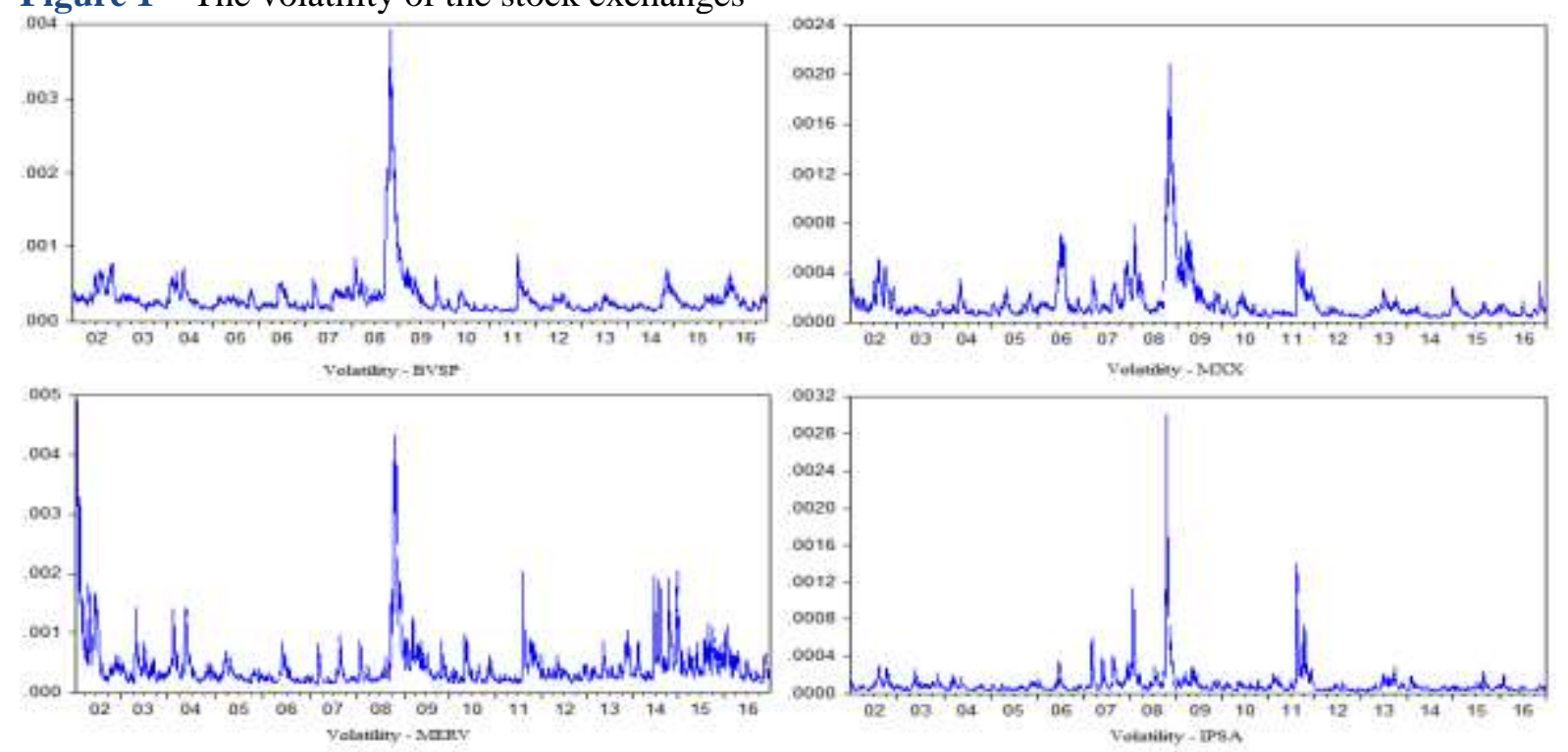

Source: Prepared by the authors.

The markets' correlations showed that all of them presented positive and high correlations due to these markets' similarity, all developing economies. However, during the period of higher volatility, the subprime crisis, the correlations displayed higher volatility between them than during the other 
periods. These findings meet Baumöhl and Lyócsa (2014) results, which demonstrated that diversification benefits decrease during more volatile periods.

Table 2 - Correlations of the markets

\begin{tabular}{|c|c|c|c|c|c|c|}
\hline Period & $\begin{array}{l}\text { BVSP x } \\
\text { MXX }\end{array}$ & $\begin{array}{l}\text { BVSP x } \\
\text { MERV }\end{array}$ & $\begin{array}{c}\text { BVSP } x \\
\text { IPSA }\end{array}$ & $\begin{array}{l}\text { MXX X } \\
\text { MERV }\end{array}$ & $\begin{array}{c}\text { MMX x } \\
\text { IPSA }\end{array}$ & $\begin{array}{c}\text { MERV } x \\
\text { IPSA }\end{array}$ \\
\hline All & 0.8998 & 0.5990 & 0.7081 & 0.5215 & 0.7185 & 0.4453 \\
\hline Before subprime crisis & 0.5792 & 0.2637 & 0.4452 & 0.1665 & 0.4996 & 0.0578 \\
\hline During subprime crisis & 0.9673 & 0.9370 & 0.7266 & 0.8982 & 0.7331 & 0.7269 \\
\hline After subprime crisis & 0.6397 & 0.5012 & 0.4944 & 0.3173 & 0.5887 & 0.3441 \\
\hline
\end{tabular}

Note: $\mathrm{BVSP}=$ Volatilidade BMF\&Bovespa; $\mathrm{MXX}=$ Volatilidade Mexbol; MERV = Volatilidade Bolsa de Comercio de Buenos Aires; IPSA = Volatilidade Bolsa de Comercio Santiago.

Source: Prepared by the authors.

Analyzing the relationship concerning the volatility of the stock exchange indices of the countries reported (Brazil, Argentina, Chile, and Mexico) and their contagion effects, it was necessary to identify whether the series were stationary or not. This analysis performed the Augmented DickeyFuller - ADF test - where the trend level and constant were verified. For situations where the constant is not significant, we redid the test without constant and trend. If there is a significance of $1 \%$, the null hypothesis is rejected, and the series has a unit root, meaning that it is stationary.

Table 3 - Unit Root Test - Augmented Dickey-Fuller

\begin{tabular}{cccc}
\hline Period & ADF & C and T & Stationary \\
\hline Brazil & $-6.572658 * * *$ & C & Stationary \\
Chile & $-10.95179^{* * * *}$ & C & Stationary \\
Argentina & $-7.346912 * * *$ & C & Stationary \\
Mexico & $-6.473240 * * *$ & C & Stationary \\
\hline
\end{tabular}

Note: *** significance $1 \%$. C and $\mathrm{T}$ indicate the presence of Constant and Trend, respectively.

Source: Prepared by the authors. 
The unit root test results for all the sample countries rejected the null hypothesis (H0). The series has a unit root, which is stationary, presenting a level of significance of $1 \%$, estimated with the constant.

A lag determination test was performed to identifies the number of lags for the VAR, presented in Table 4. The results of the test presented that should be used four lags.

Table 4 - Determination of VAR lags

\begin{tabular}{ccccccc}
\hline Lag & LogL & LR & FPE & AIC & SC & HQ \\
\hline 0 & 97830.45 & NA & $1.30 \mathrm{e}-30$ & -57.46047 & -57.45326 & -57.45789 \\
1 & 114790.5 & 33870.29 & $6.21 \mathrm{e}-35$ & -67.41292 & -67.37690 & -67.94162 \\
& & & & & & \\
2 & 115488.8 & 1393.003 & $4.16 \mathrm{e}-35$ & -67.81371 & -67.37690 & -67.94162 \\
3 & 115779.6 & 579.2958 & $3.54 \mathrm{e}-35$ & -67.97510 & -67.88144 & -67.94162 \\
4 & 115921.1 & $281.5389 *$ & $3.29 \mathrm{e}-35 *$ & $-68.04880^{*}$ & $-67.92632 *$ & $-68.00503 *$ \\
\hline
\end{tabular}

Note: LR: sequential modified LR statistical test (5\% level); FPE: prediction of Final Error; AIC: Akaike Information Criterion; SC: Schwarz Information Criteria; HQ: Hannan-Quinn Information Criteria.

Source: Prepared by the authors.

After determining the number of VAR lags, it developed a series of variance decomposition analyses, one for each country. The study of these variances has a primary objective of identifying the possible influences from one market to another. It means analyzing the correlations on the volatility behavior of the indices of the stock exchanges studied.

Table 5 presents the variance decomposition of the Brazilian stock index (Ibovespa), observing that the volatility of the Brazilian index is explained almost in its totality (92\%) by endogenous variables, which in some way influence the volatility of the market. Following the Chilean stock exchange represents 6.57\%. Finally, the Mexican and Argentine stock exchanges represent low influences on the Brazilian stock index volatility, respectively, $1.24 \%$ and $0.15 \%$. As noticed, despite the geographic proximity, countries bordering Brazil have little influence on its stock market. 
Table 5 - Decomposition of Variance BVSP (Brazil)

\begin{tabular}{cccccc}
\hline Period & S.E. & BVSPVOL & IPSAVOL & MERVVOL & MXXVOL \\
\hline 1 & $4.92 \mathrm{E}-05$ & 100.0000 & 0.000000 & 0.000000 & 0.000000 \\
5 & 0.000112 & 95.43339 & 3.657844 & 0.058564 & 0.850202 \\
10 & 0.000157 & 92.02883 & 6.570205 & 0.154965 & 1.245996 \\
\hline
\end{tabular}

Note: LR: sequential modified LR statistical test (5\% level); FPE: prediction of Final Error; AIC: Akaike Information Criterion; SC: Schwarz Information Criteria; HQ: Hannan-Quinn Information Criteria.

Source: Prepared by the authors.

The analysis of the results of Table 6, which is the variance decomposition of the Argentina stock exchange (Merval), is possible to observe that the index's volatility is explained by $70 \%$ by internal variables. The Brazilian stock exchange influence is observed in $24.79 \%$, followed by Chilean with $3.7 \%$. Finally, the Mexican stock exchange exerted only a 1.47\% influence on the Argentine stock market volatility's behavior. It is interesting to note that, even without being strongly influenced by Argentina, Brazil has considerable influence over the Argentine stock market's behavior.

Table 6 - Decomposition of Variance MERVAL (Argentina)

\begin{tabular}{cccccc}
\hline Period & S.E. & BVSPVOL & IPSAVOL & MERVVOL & MXXVOL \\
\hline 1 & $6.46 \mathrm{E}-05$ & 16.42258 & 0.006173 & 83.57125 & 0.000000 \\
5 & 0.000122 & 20.46334 & 2.813487 & 76.07099 & 0.652178 \\
10 & 0.000147 & 24.79706 & 3.707610 & 70.01859 & 1.476735
\end{tabular}

Note: LR: sequential modified LR statistical test (5\% level); FPE: prediction of Final Error; AIC: Akaike Information Criterion; SC: Schwarz Information Criteria; HQ: Hannan-Quinn Information Criteria.

Source: Prepared by the authors.

Table 7 shows the results that deal with the Mexican stock exchange variance (MXX) indicate the volatility of the Mexican index is explained by $29.16 \%$ by endogenous variables, which means that internal variables in some way influence the behavior of volatility. In contrast, the Brazilian stock exchange volatility behavior (60.52\%) influences a large part of the Mexican stock market. In sequence, the Chilean stock exchange showed an influence of $10.21 \%$, while the Argentine stock market only $0.98 \%$. 
Table 7 - Decomposition of Variance MXX (Mexico)

\begin{tabular}{cccccc}
\hline Period & S.E. & BVSPVOL & IPSAVOL & MERVVOL & MXXVOL \\
\hline 1 & $9.53 \mathrm{E}-05$ & 49.96469 & 3.002208 & 0.061028 & 46.97207 \\
5 & 0.000292 & 58.00950 & 6.331729 & 0.130293 & 35.52848 \\
10 & 0.000364 & 60.52517 & 10.21199 & 0.098663 & 29.16418 \\
\hline
\end{tabular}

Note: LR: sequential modified LR statistical test (5\% level); FPE: prediction of Final Error; AIC: Akaike Information Criterion; SC: Schwarz Information Criteria; HQ: Hannan-Quinn Information Criteria.

Source: Prepared by the authors.

According to Table 8, it is possible to notice that the internal variable explains the Chilean index volatility in $68.81 \%$. That is endogenous variables that, in some way, influence the behavior of volatility. In sequence, the Brazilian stock exchange exerts an influence of $30.48 \%$, followed by Argentina and Mexico's stock exchanges with $0.46 \%$ and $0.23 \%$, respectively.

Table 8 - Decomposition of Variance IPSA (Chile)

\begin{tabular}{cccccc}
\hline Period & S.E. & BVSPVOL & IPSAVOL & MERVVOL & MXXVOL \\
\hline 1 & $3.64 \mathrm{E}-05$ & 32.48709 & 67.51291 & 0.000000 & 0.000000 \\
5 & $7.02 \mathrm{E}-05$ & 30.01700 & 69.48663 & 0.216573 & 0.279800 \\
10 & $9.38 \mathrm{E}-05$ & 30.48008 & 68.81837 & 0.469486 & 0.232069 \\
\end{tabular}

Note: LR: sequential modified LR statistical test (5\% level); FPE: prediction of Final Error; AIC: Akaike Information Criterion; SC: Schwarz Information Criteria; HQ: Hannan-Quinn Information Criteria.

Source: Prepared by the authors.

The results show that the Brazilian market has a significant influence on $t$ some countries of the America Latina region, while the inverse influence does not happen. Besides, it noted that the Mexican stock market's volatility is weakly influenced by its internal variables, as it was determined. The more significant influence from the Brazilian stock exchange to the lowest is in Mexico, Chile, and Argentina.

After the markets' comovements analysis, it proceeded to the Generalized Response Impulse Function of Argentina (MERV), Chilean (IPSA), and Mexican (MXX) on the Brazilian stock exchange (BVSP). A shock of two standard deviations gives origin to the stock exchanges. Figures 2, 3, and 4 show these response impulses. It was analyzed only the other indices' response to the shock of two standard deviations of the variables that represent the Brazilian index. In the analysis of variance 
decomposition, this country was the only one to have a representative influence on the other indices' volatility behavior.

Figure 2 demonstrates the Argentine stock market volatility response to a shock of two standard deviations of the variable that represented the Brazilian stock exchange. An increase in the Argentine volatility index is observed in the face of a shock caused by the Brazilian stock exchange, represented after the third day. Consequently, the index shows a downward behavior, a slight improvement after the sixth day, and fall behavior to the end.

Figure 2 - Function Impulse Response (FIR) - BVSP shock over MERV

Response of BVSPVOL to MERVVOL

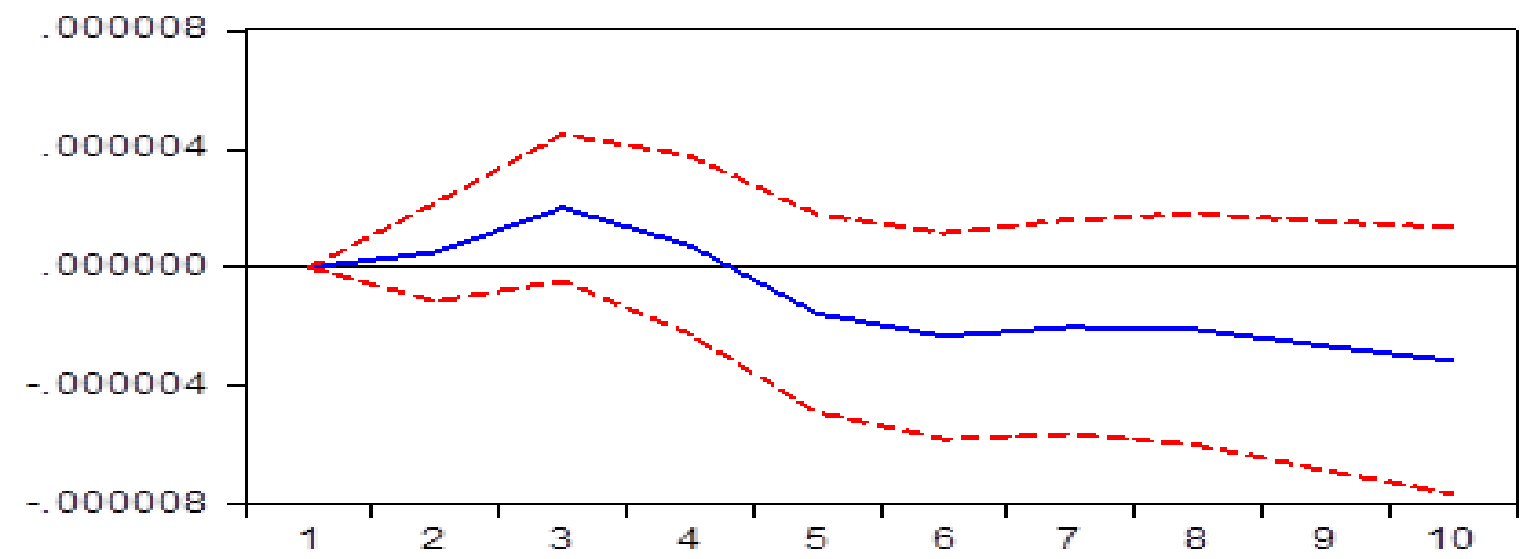

Source: Prepared by the authors.

As shown in Figure 3, the Chilean stock exchange observed an increase in the volatility index in the first few days until the second day. Right after the effect of shocks, the index reduces the index until the third day. It once again growing, showing an opposite behavior to that caused to the Argentine stock exchange, which showed a consistent fall behavior.

Figure 3 - Function Impulse Response (FIR) - BVSP shock over IPSA

$$
\text { Response of BVSPVOL to IPSAVOL }
$$

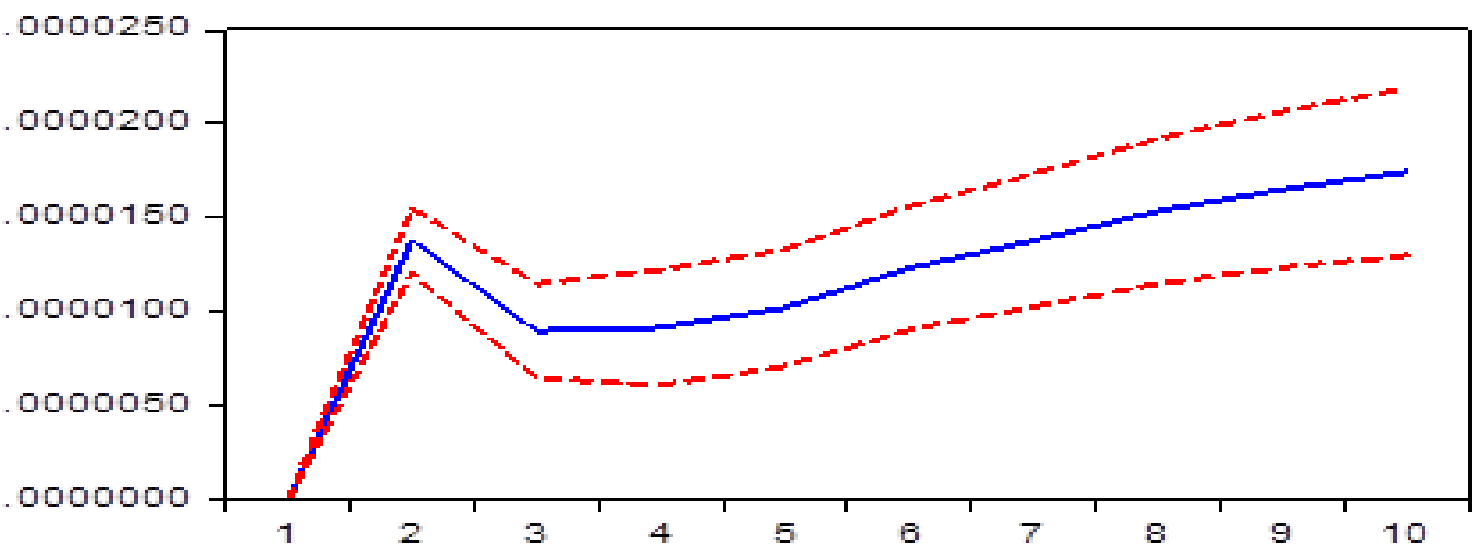

Source: Prepared by the authors. 
Figure 4, finally, presents the Mexican stock exchange behavior after the shocks of two standard deviations by the Brazilian stock exchange. It is possible to observe a behavior similar to that of the Argentine stock exchange after the shocks. The volatility index shows a steady fall behavior, with small recovery signs, but which none remain.

Figure 4 - Function Impulse Response (FIR) - BVSP shock over MXX

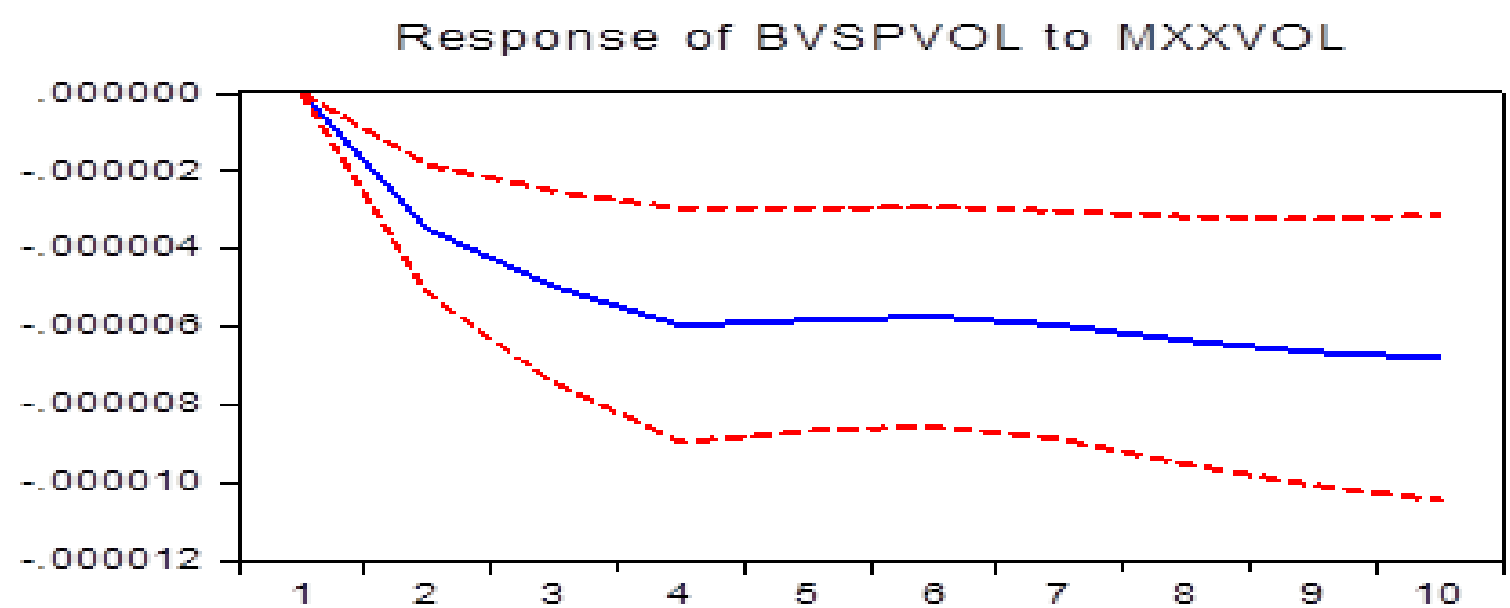

Source: Prepared by the authors

In general, the stock exchanges analyzed (Argentina, Chile, and Mexico) present some responses when they receive shocks from the Brazilian stock exchange, generally occurring in the first days, suggesting the contagion effect of volatility. This paper follows the results found by Edwards \& Susmel (2001) and Fujii (2005), which evidenced robust evidence of comovements of volatility among Latin American countries. A global financial cycle synchronizes international capital movements and asset price changes across countries. Two factors - global investors' risk preference and global uncertainty - are regarded as important global common factors that drive that cycle. The driving forces behind these comovements include the increasing openness of international trade and finance, business climate, and institutional opaqueness (Inaba, 2018).

The results indicate that during the period of higher volatility, the subprime crisis, the correlations displayed higher volatility than during the other periods. These findings meet Baumöhl and Lyócsa's (2014) results, demonstrating that diversification benefits decrease during more volatile periods. This study found that the Brazilian stock exchange has a significant influence on Argentina. When analyzing the strength of the Argentine stock exchange over the Brazilian stock market, the same influence does not occur.

Note that the other exchanges' response to the shock caused by the Brazilian exchange usually occurs. As mentioned, in the first days after the stimulus, an oscillation remains during the average period of four days. Soon after, a process of equilibrium begins observed until the end of the time series. Realize that in this case, there is a suggestion of a pattern between shock recovery behavior. Figures 2 , 3 , and 4 show that after the average of 10 days, the average volatility index shows a linear behavior, 
tending to the same initial position of the index before the shock, which reinforces the contagion effect of volatility.

Therefore, the Latin American's comovements and its ripple effects should be considered to policymakers and investors concerning financial stability and diversification opportunities, respectively. Regulators seeking financial stability should consider these movements concerning endogenous and exogenous factors of each market. The level of representativeness of the factors could lead these markets to be too exposed to external players affecting their monetary policies and seen as an opportunity for policymakers to pursue interest-rate policy more effectively and, consequently, attract investment capital. Investors should be aware when dealing in the emerging markets, that they face more risk due to not only high volatility, as already reported by previous studies, but because they present different levels of endogenous and exogenous factors among them. Thus, when investing in Latin American, investors should build portfolios and seek investments that are well diversified to diminish the ripple effects that exist among them.

\section{Conclusions}

This paper aimed to investigate the returns' volatility to check out the comovements and the contagion effects of countries from Latin American countries. The sample comprises daily data from January 2002 to December 2016 to measure the volatility of countries' stock exchanges from Latin America. We used an Autoregressive model with Conditional Heteroscedasticity, ARCH/GARCH models to measure the volatility. To check the stock exchanges' contagion effects, we use volatility models, vector autoregression models (VAR).

The results indicate evidence of a contagion effect in all countries, with two facts being relevant. The first is the influence of the Brazilian stock exchange in all other countries in the sample and, lastly, the low representativeness of endogenous factors to explain the volatility behavior of the stock exchange from Mexico. We found that diversification benefits decrease during more volatile periods. The Brazilian stock exchange has a significant influence on Argentina. The same influence does not occur when analyzing the strength of the Argentine stock exchange over the Brazilian stock market.

Therefore, the Latin American's comovements and its ripple effects should be considered to policymakers and investors concerning financial stability and diversification opportunities, respectively. The study's limitations are the sample of Latin American stock exchanges, selected due to the consulted database's availability of information. Thus, it is possible to suggest future research to work with a larger sample of Latin American countries and use a multivariate approach to build portfolios regarding their comovements and some strategic partner countries' stock exchange for the Latin American markets. 


\section{References}

Ahmed, N., \& Sarfraz, M. (2013). Traditional Methods to Measure Volatility: Case Study of Selective Developed and Emerging Markets. Research Journal of Finance and Accounting, 4(7), 161-166.

Aloui, R., Aïssa, M. S. B., \& Nguyen, D. K. (2011). Global financial crisis, extreme interdependences, and contagion effects: The role of economic structure?. Journal of Banking \& Finance, 35(1), 130141.

Andersen, T. G., Bollerslev, T., Diebold, F. X., \& Ebens, H. (2001). The distribution of realized stock return volatility. Journal of financial economics, 61(1), 43-76.

Ang, A., \& Bekaert, G. (2002). International ass et al location with regime shifts. The Review of Financial Studies, 15(4), 1137-1187.

Baumöhl, E., \& Lyócsa, Š. (2014). Volatility and dynamic conditional correlations of worldwide emerging and frontier markets. Economic Modelling, 38, 175-183.

Bollerslev, T., Chou, R. Y., \& Kroner, K. F. (1992). ARCH modeling in finance: A review of the theory and empirical evidence. Journal of econometrics, 52(1-2), 5-59.

Broto, C., Díaz-Cassou, J., \& Erce, A. (2011). Measuring and explaining the volatility of capital flows to emerging countries. Journal of banking \& finance, 35(8), 1941-1953.

Chen, G. M., Firth, M., \& Rui, O. M. (2002). Stock market linkages: evidence from Latin America. Journal of Banking \& Finance, 26(6), 1113-1141.

Corsetti, G., Pericoli, M., \& Sbracia, M. (2005). 'Some contagion, some interdependence': More pitfalls in tests of financial contagion. Journal of International Money and Finance, 24(8), 11771199.

De Santis, G. (1997). Stock returns and volatility in emerging financial markets. Journal of International Money and Finance, 16(4), 561-579.

Edwards, S., \& Susmel, R. (2001). Volatility dependence and contagion in emerging equity markets. Journal of Development Economics, 66(2), 505-532.

Forbes, K. J., \& Rigobon, R. (2002). No contagion, only interdependence: measuring stock market comovements. The journal of Finance, 57(5), 2223-2261.

French, K. R., Schwert, G. W., \& Stambaugh, R. F. (1987). Expected stock returns and volatility. Journal of Financial Economics, 19(1), 3-29.

Fujii, E. (2005). Intra and inter-regional causal linkages of emerging stock markets: evidence from Asia and Latin America in and out of crises. Journal of International financial markets, Institutions and Money, 15(4), 315-342.

Gaio, L. E., Pessanha, G. R. G., de Oliveira, D. R., \& de Ázara, L. N. (2007). Análise da volatilidade do índice Bovespa: um estudo empírico utilizando modelos da classe ARCH. Contextus - Revista Contemporânea de Economia e Gestão, 5(1), 7-16.

Glosten, L. R., Jagannathan, R., \& Runkle, D. E. (1993). On the relation between the expected value and the volatility of the nominal excess return on stocks. The Journal of Finance, 48(5), 1779-1801.

Harvey, C. R. (1995). Predictable risk and returns in emerging markets. The review of financial studies, 8(3), 773-816. 
Inaba, K. I. (2018). Global Stock Return Comovements: Trends and Determinants (No. 18-E-7). Bank of Japan.

Kaminsky G. L. Reinhart C., 2000, “On Crises, Contagion and Confusion”. Journal of International Economics, 51(1), 145-168.

Longin, F., \& Solnik, B. (2001). Extreme correlation of international equity markets. The journal of finance, 56(2), 649-676.

Longstaff, F. A. (2010). The subprime credit crisis and contagion in financial markets. Journal of financial economics, 97(3), 436-450.

Markowitz, H. (1952). Portfolio selection. The journal of finance, 7(1), 77-91.

Morettin, P. A. (2004). Econometria Financeira: Um Curso de Séries Temporais Financeiras. São Paulo, Blucher.

Panda, A. K. and Nanda, S. (2018) 'Time-varying synchronization and dynamic conditional correlation among the stock market returns of leading South American economies', International Journal of Managerial Finance, 14(2), 245-262

Patton, A. J. (2004). On the out-of-sample importance of skewness and asymmetric dependence for asset allocation. Journal of Financial Econometrics, 2(1), 130-168.

Pericoli, M., \& Sbracia, M. (2003). A primer on financial contagion. Journal of Economic Surveys, 17(4), 571-608.

Perobelli, F. F. C., Vidal, T. L., \& Securato, J. R. (2013). Avaliando o efeito contágio entre economias durante crises financeiras. Estudos Econômicos (São Paulo), 43(3), 557-594.

Poon, S. H., Rockinger, M., \& Tawn, J. (2003). Extreme value dependence in financial markets: Diagnostics, models, and financial implications. The Review of Financial Studies, 17(2), 581-610.

Sarwar, G. (2019) 'Transmission of Risk Between U. S. and Emerging Equity Markets', Emerging Markets Finance and Trade, 55(5), 1171-1183

Schwert, G. W. (1989). Why does stock market volatility change over time?. The Journal of Finance, 44(5), 1115-1153.

Vartanian, P. R. (2012). Impactos do índice Dow Jones, commodities e câmbio sobre o Ibovespa: uma análise do efeito contágio. RAC-Revista de Administração Contemporânea, 16(4). 